\title{
Isolation and characterization of twelve polymorphic microsatellite loci for Hypochaeris catharinensis (Asteraceae) and cross-amplification in related species
}

\author{
CAMILA LUCAS CHAVES ${ }^{1}$, CLAUDETE DE FÁTIMA RUAS ${ }^{2}$, PAULO MAURÍCIO RUAS ${ }^{1,2 *}$, \\ ANGELO ALBERTO SCHNEIDER ${ }^{3}$, KÁTIA REAL ROCHA $^{2}$, ESTRELLA URTUBEY ${ }^{4}$ \\ and EDUARDO AUGUSTO RUAS ${ }^{2}$ \\ ${ }^{1}$ Departamento de Agronomia, and ${ }^{2}$ Departamento de Biologia Geral, Centro de Ciências Biológicas, Universidade \\ Estadual de Londrina, 86051-990 Londrina, Paraná, Brazil \\ ${ }^{3}$ Fundação Estadual de Pesquisa Agropecuária, Centro Anacreonte Ávila de Araújo, São Gabriel, Br 290, km 412, \\ Rio Grande do Sul, Brazil \\ ${ }^{4}$ Instituto de Botánica Darwinion, Labardén 200, CC 22, San Isidro, Argentina
}

\begin{abstract}
[Chaves C. L., Ruas C. F., Ruas P. M., Schneider A. A., Rocha K. R., Urtubey E. and Ruas E. A. 2015 Isolation and characterization of twelve polymorphic microsatellite loci for Hypochaeris catharinensis (Asteraceae) and cross-amplification in related species. J. Genet. 94, e39-e42. Online only: http://www.ias.ac.in/jgenet/OnlineResources/94/e39.pdf]
\end{abstract}

\section{Introduction}

In this study, we describe the development and screening of an enriched genomic DNA library aiming to identify microsatellite loci in Hypochaeris catharinensis, an endemic species from southern Brazil. Twelve polymorphic microsatellite loci tested in a sample of 60 individuals from three different populations of $H$. catharinensis, identified 98 alleles with an average of 8.17 alleles per locus. The average polymorphic information content (PIC) varied from 0.098 to 0.757 , with five loci exhibiting significant deviation from Hardy-Weinberg equilibrium (HWE). Transferability test for cross-amplification was done in 10 related Hypochaeris species with a rate of success ranging from 12 loci, for $H$. petiolaris and $H$. varigata, to six loci for $H$. patagonica. These microsatellite loci will provide valuable information for studying genetic diversity, population genetic structure, conservation biology and for understanding the past demographic events of $H$. catharinensis and other related species of Hypochaeris.

Hypochaeris is considered as a biological model to understand evolutionary processes in the vascular flora of South America, particularly from the temperate portion of the continent. As suggested by molecular clock dating, the South American species of Hypochaeris was derived from a common ancestor from northwest Africa that arrived in the continent between 3.5 and 0.25 mya by long-distance dispersal

\footnotetext{
*For correspondence. E-mail: pmruas@uel.br.
}

(Tremetsberger et al. 2005). Following rapid events of adaptive radiation in the continent, the genus dispersed (between 0.25 and 1.00 mya) into new habitats, developing great deal of morphological variation (Stuessy et al. 2003; Tremetsberger et al. 2006). Evidence of adaptive radiation, producing ecologically restricted and morphologically distinct taxa, has been documented in plants (Sang et al. 1994; Kim et al. 2008). For instance, molecular data based on plastid DNA (ITS, matK, trnL-F) revealed that the genus Hypochaeris is monophyletic in South America, although amplified fragment length polymorphism (AFLP) analyses resolved six different independent lineages within the continent (Stuessy et al. 2003; Tremetsberger et al. 2006).

In Brazil, Hypochaeris is represented by eight to ten species, mostly endemic to the southern region where $H$. catharinensis Cabrera can be cited as an example of a species with unique morphological and ecological characteristics. The distribution of $H$. catharinensis comprises the north of Rio Grande do Sul and south of Santa Catarina states, occurring exclusively at altitudes up to $1400 \mathrm{~m}$, in areas where the temperature in winter is below $-1{ }^{\circ} \mathrm{C}$, with incidence of dry, rocky and shallow soils, characterizing a nutrient-poor environment (Azevêdo-Gonçalves and Matzenbacher 2007). Adaptation to this environment is facilitated by horizontal rhizomes, a feature of taxonomic importance (AzevêdoGonçalves and Matzenbacher 2007) that also influences the vegetative spread of the species. Morphologically, $H$. catharinensis has rose-like leaves, forming a rosette that favours the total light incidence, a solitary stem, capitula

Keywords. enriched genomic libraries; genetic diversity; Hypochaeris; simple sequence repeats. 
enclosing florets with yellow corolles and beaked achenes (Azevêdo-Gonçalves and Matzenbacher 2007).

Until recently, $H$. catharinensis was only known by its ecology and morphological characters. However, recent reports based on cytogenetic studies included $H$. catharinensis within a chromosomal group described for the South American species of Hypochaeris, while AFLP data provided evidence that $H$. catharinensis constitutes a new phylogenetic lineage with the sister-species $H$. lutea (Reck et al. 2011). Studies at population level are important to understand the potential for broad and rapid speciation of Hypochaeris in South America, but information at population level is still lacking for the species H. catharinensis.

Since microsatellite markers (SSR) have become the preferred tool for genetic studies in a variety of organisms, especially as a result of the high level of polymorphism, codominant nature, multiallelism and reproducibility, this paper describes the development and screening of a microsatellite-enriched library for $H$. catharinensis, to study genetic diversity, population genetic structure, conservation biology and to understand past demographic events of $H$. catharinensis and closely-related species. Such studies could test the assumption of a recent evolution and biogeographic emergence of the genus Hypochaeris in the South American continent.

\section{Materials and methods}

Genomic DNA of $H$. catharinensis and related species was extracted from fresh leaves using the cetyltrimethylammonium bromide (CTAB) method (Doyle and Doyle 1987). An enriched microsatellite library was constructed using DNA of one individual of $H$. catharinensis by the hybridization based capture method with biotinlabelled $(\mathrm{CT})_{8}$ and $(\mathrm{GT})_{8}$ oligonucleotides (Billotte et al. 1999). DNA $(5 \mu \mathrm{g})$ was digested with RsaI (Promega, Madison, USA) and blunt-ended fragments were linked to adapters (Rsa-21 and Rsa-25). Fragments containing repeats were selected by hybridization with the biotinylated oligonucleotides and recovered by streptavidin-coated magnetic beads (Invitrogen-Dynal, Lillestrøm, Norway). Microsatellite-rich fragments were amplified by PCR with the Rsa 21 adapter and cloned into the pGEM-T Easy vector II (Promega). Recombinant clones (98) were randomly selected and double-sequenced with M13 forward and reverse primers using an ABI 3500xl Genetic Analyzer (Applied Biosystems, New York, USA). A total of 36 clones were found possessing motifs with perfect compound and interrupted microsatellite and 20 of them showed flanking regions adequate for primers design (Primer3Plussoftware; Untergasser et al. 2007).

Annealing temperature and amplification consistency for each primer pair were tested in a sample of five individuals of $H$. catharinensis. Twelve of the 20 primer pairs provided clear and consistent amplification pattern and they were applied for genotyping a sample of 60 individuals of $H$. catharinensis, representing three native populations (20 individuals of each) from southern Brazil (two populations from Santa Catarina state: Rancho Queimado - $27^{\circ} 38^{\prime} \mathrm{S}, 48^{\circ} 59^{\prime} \mathrm{W}$ and Caçador-BR153-26 $34^{\circ} \mathrm{S}, 51^{\circ} 44^{\prime} \mathrm{W}$; one population from Rio Grande do Sul state, Cambará do Sul-29 $10^{\prime} \mathrm{W}$ ). Vouchers were deposited at the Herbarium FUEL, Universidade Estadual de Londrina under the identification numbers: FUEL 40696 (Rancho Queimado), FUEL 50926 (CaçadorBr153) and FUEL 42237 (Cambará do Sul). For genotyping, we used indirect fluorescent labelling of fragments with a three-primer system (Schuelke 2000), with the forward primers tagged with M13 sequences (TGTAAAACGACG GCCAGT) at the $5^{\prime}$ end. The standard PCR reactions were in a $10 \mu \mathrm{L}$ volume containing $4.5 \mu \mathrm{L}$ GoTaq Green Master Mix (Promega), $0.08 \mu \mathrm{L}$ of M13-tailed forward primer, $0.32 \mu \mathrm{L}$ of reverse primers (table 1) and $0.32 \mu \mathrm{L}$ of M13-labelled (6-FAM, HEX or NED) primers, $2 \mu \mathrm{L}$ (30 ng) of genomic DNA and $2.78 \mu \mathrm{L}$ of nuclease free water. PCR amplification profiles consisted of an initial denaturation of $4 \mathrm{~min}$ at $94^{\circ} \mathrm{C}$, followed by 16 touchdown cycles at $94^{\circ} \mathrm{C}$ for $30 \mathrm{~s}, 65-50^{\circ} \mathrm{C}$ $\left(-1^{\circ} \mathrm{C}\right.$ per cycle) for $30 \mathrm{~s}, 72^{\circ} \mathrm{C}$ for $1 \mathrm{~min}$, followed by 30 additional cycles at $94^{\circ} \mathrm{C}$ for $30 \mathrm{~s}, 50^{\circ} \mathrm{C}$ for $30 \mathrm{~s}$ and $72^{\circ} \mathrm{C}$ for $1 \mathrm{~min}$, with a final extension at $72^{\circ} \mathrm{C}$ for $7 \mathrm{~min}$. The PCR products were run in the ABI 3500-xl Genetic Analyzer (Applied Biosystems).

For characterization of the polymorphic loci, we applied standard population genetic statistics, calculated using Cervus ver 2.0 software (Marshall et al. 1998) and GENEPOP ver. 1.2 (Raymond and Rousset 1995). Linkage disequilibrium was tested by sequential Bonferroni correction for multiple comparisons at 5\% significance. Presence of null alleles was verified using the software Micro-Checker 2.2.3 (Van-Oosterhout et al. 2004).

\section{Results and discussion}

The genotyping of 60 individuals of $H$. catharinensis identified a total of 98 alleles, ranging from 152 (Hcat2) to $264 \mathrm{bp}$ (Hcat3), and a moderate level of polymorphism. The number of alleles per locus ranged from three (Hcat3) to 14 (Hcat21), with an average of 8.17 alleles per locus (table 1). PIC ranged from 0.064 (Hcat6) to 0.757 (Hcat14), whereas levels of observed $\left(H_{\mathrm{o}}\right)$ and expected $\left(H_{\mathrm{e}}\right)$ heterozygosity varied from 0.000 (Hcat3) to 0.804 (Hcat24) and from 0.066 (Hcat6) to 0.792 (Hcat14) with mean values of 0.325 and 0.498 , respectively (table 1 ).

Five loci showed allelic frequencies that significantly deviated from expected HWE proportions, with loci Hcat3, Hcat14, Hcat17 been significant at $P \leq 0.001$ and loci Hcat 21 and Hcat24a were significant at $P \leq 0.05$. Pairwise comparisons for multiple tests among the polymorphic loci showed significant linkage disequilibrium only between loci Hcat24a/Hcat24b and Hcat14/Hcat17, while six loci showed significant evidence for the presence of null alleles according 
Table 1. Characterization of 12 polymorphic microsatellite loci genotyped in 60 individuals from three populations of $H$. catharinensis.

\begin{tabular}{|c|c|c|c|c|c|c|c|c|}
\hline $\begin{array}{l}\text { Locus/GenBank } \\
\text { accession no. }\end{array}$ & Primer sequence $\left(5^{\prime}-3^{\prime}\right)$ & Repeat motif & $T_{\mathrm{A}}$ & $\begin{array}{l}\text { Allele } \\
\text { size }\end{array}$ & $K$ & $H_{\mathrm{o}}$ & $H_{\mathrm{e}}$ & PIC \\
\hline Hcat1 KF157558 & $\begin{array}{l}\text { F: ATTGCAACCCTTTGCAACTT } \\
\text { R: CATATTTGTGGGATAAAGGTCA }\end{array}$ & $\mathrm{CA}_{4}$ & 59 & $213-249$ & 5 & 0.086 & 0.101 & 0.098 \\
\hline Hcat2 KF157559 & $\begin{array}{l}\text { F: CACTTGAAATCGTCCCTCTCA } \\
\text { R: AATGTCAAGCCAAGCCAGTC }\end{array}$ & $(\mathrm{GT})_{6} \mathrm{GA}(\mathrm{GT})_{3}$ & 59 & $154-249$ & 11 & 0.458 & 0.416 & 0.392 \\
\hline Hcat3 KF157560 & $\begin{array}{l}\text { F: TTCTGCTGCTTTGCTTCTGA } \\
\text { R: AAACCCCTACTGCCAGACCT }\end{array}$ & $\mathrm{GA}_{5}$ & 60 & $260-264$ & 3 & $0.000 * *$ & 0.643 & 0.564 \\
\hline Hcat6 KF157561 & $\begin{array}{l}\text { F: AATTCGGGAGGTTCCCTTTA } \\
\text { R: ACATGAAGGGACGAGTCAGG }\end{array}$ & $(\mathrm{TTC})_{4} \mathrm{TTA}(\mathrm{TTC})$ & 60 & $222-225$ & 4 & 0.017 & 0.066 & 0.064 \\
\hline Hcat7 KF157562 & $\begin{array}{l}\text { F: TCAAGGGTTCTCCCAACAAC } \\
\text { R: GATCAACGTAGCCAGGTGGT }\end{array}$ & $(\mathrm{CT})_{2} \mathrm{CCAA}(\mathrm{CT})_{5}$ & 60 & $164-246$ & 6 & 0.183 & 0.230 & 0.218 \\
\hline Hcat8 KF157563 & $\begin{array}{l}\text { F: GAATGTAGCGGGATCGTT } \\
\text { R: ATGTCGGGGACGGATCTACT }\end{array}$ & $(\mathrm{CA}) \mathrm{AA}(\mathrm{CA})_{4}$ & 60 & $164-216$ & 6 & 0.621 & 0.495 & 0.407 \\
\hline Hcat14 JX418274 & $\begin{array}{l}\text { F: ATAACCGTCTGATGCCAAGC } \\
\text { R: CCCAATCTTGAAGCTGGAAA }\end{array}$ & $(\mathrm{CTT})_{3} \mathrm{n}(\mathrm{CTA})_{3}$ & 60 & $164-226$ & 12 & $0.217 * *$ & 0.792 & 0.757 \\
\hline Hcat17 JX418277 & $\begin{array}{l}\text { F: ACACATGAGAAGGGCGATTT } \\
\text { R: GGTTCCCTATTGCGTTGAAA }\end{array}$ & $(\mathrm{TG})_{4} \mathrm{n}(\mathrm{TG})_{3}$ & 59 & $162-226$ & 9 & $0.217 * *$ & 0.747 & 0.707 \\
\hline Hcat19 JX418273 & $\begin{array}{l}\text { F: AACAAGCAAAACCCAGGATG } \\
\text { R: CATCACCACCСCСТCTTCTA }\end{array}$ & $(\mathrm{TCTG})_{6} \mathrm{n}(\mathrm{GT})_{5}(\mathrm{TG})_{4}$ & 59 & $213-225$ & 6 & 0.133 & 0.218 & 0.211 \\
\hline Hcat21 JX418272 & $\begin{array}{l}\text { F: TGCGTGGTTGAATTCTTTGT } \\
\text { R: CAAACCAGCACCCTGAAAAT }\end{array}$ & $(\mathrm{CT})_{3} \mathrm{TT}(\mathrm{CT})_{19}$ & 59 & $183-227$ & 14 & $0.424 *$ & 0.787 & 0.752 \\
\hline Hcat24a JX418275 & $\begin{array}{l}\text { F: TGGCTGCCCTTTATACTTGC } \\
\text { R: CGGGAGTATGTATGCGTGTG }\end{array}$ & $(\mathrm{GA})_{7} \mathrm{n}(\mathrm{AGG})_{5}$ & 60 & $185-227$ & 11 & $0.741 *$ & 0.749 & 0.715 \\
\hline Hcat24b JX418276 & $\begin{array}{l}\text { F: GCCATGCTTTCTCCCTTTCT } \\
\text { R: GCTTACGCGTGGACTAGCAT }\end{array}$ & $(\mathrm{CT})_{3} \mathrm{n}(\mathrm{AC})_{11}$ & 60 & $183-227$ & 11 & 0.804 & 0.741 & 0.702 \\
\hline
\end{tabular}

$T_{\mathrm{A}}$, anneling temperature $\left({ }^{\circ} \mathrm{C}\right)$; allele size indicates the range of observed alleles in bp; $K$, number of alleles; $H_{\mathrm{O}}$ and $H_{\mathrm{e}}$, observed and expected heterozygosities, respectively; PIC, polymorphic information content; *significant deviation from with $P \leq 0.05$ and $* *$ with $P \leq 0.001$.

Table 2. Cross-amplification test of 12 microsatellite loci throughout 10 species of genus Hypochaeris.

Species Hcat1 Hcat2 Hcat3 Hcat6 Hcat7 Hcat8 Hcat14 Hcat17 Hcat19 Hcat21 Hcat24a Hcat24b

H. albiflora (Kuntze) Azevêdo-Gonç. $+\quad+\quad-\quad+\quad+\quad+\quad+\quad+\quad+\quad+$

\& Matzenb

H. angustifolia (Litard. \& Maire) Maire $+\quad+\quad+\quad+\quad+\quad+\quad+\quad+$

H. argentina Cabrera

H. chillensis (Kunth)

H. lutea (Vell.) Britton

H. megapotamica Cabrera

H. pampasica Cabrera

H. patagonica Cabrera

H. petiolaris (Hook. \& Arn.) Griseb.

H. variegata (Lam.) Baker

$\begin{array}{llllll}+ & + & + & + & + & + \\ + & + & + & + & + & + \\ + & + & + & + & + & + \\ + & + & - & + & + & + \\ + & + & + & + & + & + \\ + & + & - & + & + & + \\ - & + & - & + & + & + \\ + & + & + & + & + & + \\ + & + & + & + & + & +\end{array}$

+ , Clear amplification; -, no amplification.

to Bonferroni correction $(P \leq 0.05)$, caused probably to homozygosis excess.

The 12 isolated microsatellite loci were tested for crossamplification in 10 South American representatives of Hypochaeris including $H$. angustifolia, the presumed ancestor of this group. Four primer pairs (Hcat2, Hcat6, Hcat7 and Hcat8) showed amplifications in all species tested and in $H$. angustifolia, while the transferability rate of the other loci varied from five to nine species (table 2).
The levels of variation detected for the 12 microsatellite loci revealed the high potential of these markers for applications in genetic diversity, population genetic structure and studies of past demographic events of $H$. catharinensis. High levels of cross-species transferability of microsatellite loci is only expected in closely-related species (Selkoe and Toonen 2006; Souza et al. 2009; Rai et al. 2013). Therefore, the crossamplification success of the $H$. catharinensis microsatellites also suggests that these markers can be efficiently applied for 
genetic studies of other Hypochaeris species, thus providing valuable information to understand the potential for broad and rapid speciation of the genus in South America.

\section{Acknowledgements}

This work was supported by the Brazilian agencies: CNPQ Conselho Nacional de Desenvolvimento Científico e Tecnológico (nos. 201254/2003-4 and 201332/2003-5), Fundação AraucáriaFundação de Amparo à Pesquisa do Estado do Paraná (no. 024/2007, protocol no. 9791) and CAPES-Coordenação de Aperfeiçoamento de Pessoal de Nível Superior for scholarships to Ph.D. students and grants (PNPD no. 2238/2009) to postdoctoral associates.

\section{References}

Azevêdo-Gonçalves C. F. and Matzenbacher N. I. 2007 O gênero Hypochaeris L. (Asteraceae) no Rio Grande do Sul, Brasil. Iheringia Sér. Bot. 62, 55-87.

Billotte N., Lagoda P. J. R., Risterucci A. M. and Baurens F. C. 1999 Microsatellite-enriched libraries: applied methodology for the development of SSR markers in tropical crops. Fruits 54, 277-288.

Doyle J. J. and Doyle J. L. 1987 A rapid isolation procedure for small quantities of fresh leaf tissue. Phytochem. Bull. 19, 11-15.

Kim S. C., McGowen M. R., Lubinsky P., Barber J. C., Mort M. E. and Santos-Guerra A. 2008 Timing and tempo of early and successive radiations in Macaronesia. PLoS One 3, 2139.

Marshall T. C., Slate J., Kruuk L. and Pemberton J. M. 1998 Statistical confidence for likelihood-based paternity inference in natural populations. Mol. Ecol. 7, 639-655.

Qin Y., Xu T., Wang R. and Shi G. 2012 Isolation and characterization of polymorphic microsatellites for silver pomfret. J. Genet. 91, 79-81.

Rai M. K., Phulwaria M. and Shekhawat N. S. 2013 Transferability of simple sequence repeat (SSR) markers developed in guava (Psidium guajava L.) to four Myrtaceae species. Mol. Biol. Rep. 40, 5067-5071.
Raymond M. and Rousset F. 1995 GENEPOP (version 1.2): population genetics software for exact tests and ecumenicism. J. Heredity 86, 248-249.

Reck M., Benício L. M., Ruas E. A., Rodrigues L. A., Ruas P. M., Ortiz M. A. et al. 2011 Karyotype and AFLP data reveal the phylogenetic position of the Brazilian endemic Hypochaeris catharinensis (Asteraceae). Plant Syst. Evol. 296, 231-243.

Ruas E. A., Damasceno J. O., Conson A. R. O., Costa B. F., Rodrigues L. A., Reck M. et al. 2011 Isolation and characterization of eleven polymorphic microsatellite loci in Aegiphila and their transferability. Biol. Plant 55, 296-299.

Sang T., Crawford D. J., Kim S. C. and Stuessy T. F. 1994 Radiation of the endemic genus Dendroseris (Asteraceae) on the Juan Fernandez Islands: evidence from sequences of the ITS regions of nuclear ribosomal DNA. Am. J. Bot. 81, 1494-1501.

Schuelke M. 2000 An economic method for the fluorescent labelling of PCR fragments. Nat. Biotechnol. 18, 233-234.

Selkoe K. A. and Toonen R. J. 2006 Microsatellites for ecologists: a practical guide to using and evaluating microsatellite markers. Ecol. Lett. 9, 615-629.

Souza L. M., Mantello C. C., Santos M. O., Souza Gonçalves P. and Souza A. P. 2009 Microsatellites from rubber tree (Hevea brasiliensis) for genetic diversity analysis and cross-amplification in six Hevea wild species. Conserv. Genet. Resour. 1, 75-79.

Stuessy T. F., Tremetsberger K., Müllner A. N., Jankowicz J., Guo Y. P., Baeza C. M. and Samuel R. M. 2003 The melding of systematics and biogeography through investigations at the populational level: examples from the genus Hypochaeris (Asteraceae). Basic Appl. Ecol. 4, 287-296.

Tremetsberger K., Weiss-Schneeweiss H., Stuessy T. F., Samuel R., Kadlec G., Ortiz M. A. and Talavera S. 2005 Nuclear ribosomal DNA and karyotypes indicate a NW African origin of South American Hypochaeris (Asteraceae, Cichorieae). Mol. Phylogenet. Evol. 36, 102-116.

Tremetsberger K., Stuessy T. F., Kadlec G., Urtubey E., Baeza C. M., Beck S. G. et al. 2006 AFLP phylogeny of South American species of Hypochaeris (Asteraceae, Lactuceae). Syst. Bot. 3, 610-626.

Untergasser A., Nijveen H., Rao X., Bisseling T., Geurts R. and Leunissen J. A. M. 2007 Primer3Plus, an enhanced web interface to Primer3. Nucleic Acids Res. 35, 71-74.

Van-Oosterhout C., Hutchinson W. F., Wills D. P. M. and Shipley P. 2004 MICRO-CHECKER: software for identifying and correcting genotyping errors in microsatellite data. Mol. Ecol. Notes 4, 535-538. 